\title{
ENAMEL MICROSTRUCTURE IN EXAERETODON, A LATE TRIASSIC SOUTH AMERICAN TRAVERSODONTID (THERAPSIDA: CYNODONTIA)
}

\author{
FERNANDOABDALA \\ Bernard Price Institute for Palaeontological Research, University of the Witwatersrand \\ WITS 2050, Johannesburg, South Africa.nestor.abdala@wits.ac.za \\ MARIA CLAUDIA MALABARBA \\ Museu de Ciências e Tecnologia, PUCRS, Av. Ipiranga, 6681, 90619-900, Porto Alegre, RS, Brazil. \\ mariacm@pucrs.br
}

\begin{abstract}
Exaeretodon is a well-known traversodontid cynodont mostly confined to the Upper Triassic of Argentina and Brazil. In this paper, the enamel structures of the upper postcanines of Exaeretodon frenguellii from the Ischigualasto Formation, northwestern Argentina, and of E. riograndensis from the Santa Maria Formation, southern Brazil, are examined using scanning electron microscopy. In E. frenguellii, the prismless enamel layer is usually thicker than $100 \mu \mathrm{m}$ and comprised of parallel, short, discontinuous columns perpendicular to the outer enamel surface. Exaeretodon riograndensis also presents a prismless enamel layer thicker than $100 \mu \mathrm{m}$, made up of vaguely defined columns, with abundant and well-defined incremental lines. Dentine was also examined in different areas exposed to, and hidden from occlusion in E. frenguellii. In sagittal section, abundant dorsoventrally-oriented tubules are clearly observed in the dentine not exposed to occlusion, whereas they seem to be less abundant and certainly less evident in dentine exposed to occlusion. This difference might simply represent a change in the orientation of the tubules.
\end{abstract}

Key words: Enamel microstructure, traversodontid cynodont, columnar enamel.

\begin{abstract}
RESUMO - Exaeretodon é um típico cinodonte traversodontídeo que ocorre principalmente no Triássico Superior da Argentina e do Brasil. Neste trabalho, a microestrutura do esmalte em pós-caninos superiores de Exaeretodon frenguellii da Formação Ischigualasto, noroeste da Argentina e de E. riograndensis da Formação Santa Maria, sul do Brasil, é examinada através de microscópio eletrônico de varredura. Em E. frenguellii, a camada de esmalte é espessa $(>100 \mu \mathrm{m})$ e compreende colunas paralelas, curtas e descontínuas, perpendiculares à superfície externa do esmalte. Exaeretodon riograndensis também apresenta uma camada de esmalte espessa $(>100 \mu \mathrm{m})$ formada por colunas mal definidas, e atravessada por abundantes linhas de crescimento. A dentina de E. frenguellii também foi examinada em áreas da bacia occlusal e em áreas internas do dente nao exposta ao oclusão. Em corte sagital, se observa claramente uma abundância de túbulos orientados dorso-ventralmente na dentina não exposta a oclusão; enquanto eles parecem ser menos abundantes e, certamente, menos evidente na dentina exposta a oclusão. Esta diferença pode representar apenas uma mudança na orientação dos túbulos.
\end{abstract}

Palavras-chave: Microestrutura do esmalte, cinodonte traversodontideo, esmalte colunar.

\section{INTRODUCTION}

Enamel microstructure in nonmammaliaform synapsids continues to be an important topic in ongoing studies of tooth, in light of the central role played by the origin of enamel prisms in the evolution of synapsid dentitions (Stern \& Crompton, 1995; Clemens, 1997; Wood \& Stern, 1997; Sander, 2000; Wood \& Rougier, 2005). Thus, Grine \& Vrba (1980) proposed a correlation between the reduction of dental replacement (diphyodonty) in mammals and the presence of enamel prisms. Likewise, the increase of the resistance of enamel to wear was interpreted as related to an increase in complexity in enamel microstructure in nonmammaliaform cynodonts and basal Mammaliaformes (Crompton et al.,
1994). In this context, nonmammaliaform cynodonts are in a crucial position because they are the synapsids that are more closely related to Mammaliaformes (= Mammals of Hopson \& Barghusen, 1986 and Luo, 1994, among others). Consequently, the enamel microstructure of many southern African and some European and North American nonmammaliaform cynodonts have been surveyed (see Sander, 1997 for a recent review). Notwithstanding the high diversity of South American nonmammaliaform cynodonts, few reports are known that take into account their enamel microstructure (Osborn \& Hillman, 1979; Stern \& Crompton, 1995). The traversodontid cynodont Massetognathus from the Middle Triassic of Argentina was the only taxon studied using scanning electron microscopy (Stern \& Crompton, 1995). 
Traversodontids are omnivorous/herbivorous cynodonts showing a bilateral postcanine occlusion system, which predates the precise complex occlusion developed later by mammals (Crompton, 1972; Hopson, 1984; Crompton et al., 1994). This group is particularly well represented in South America (Bonaparte, 1982; Abdala \& Ribeiro, 2003), where they display the greatest diversity in the world, with at least 10 genera, many of these represented by numerous specimens. Exaeretodon is a large South American traversodontid, reaching a body length of up to two meters, typically represented in the Carnian of Argentina and Brazil (Abdala et al., 2002). In this contribution, we describe the enamel microstructure of two species of South American traversodontids: Exaeretodon frenguellii Cabrera, 1954 from the Ischigualasto Formation, northwestern Argentina, and E. riograndensis Abdala et al., 2002 from the Santa Maria Formation of southern Brazil. We compare our results with enamel microstructures described for other nonmammaliaform synapsids, including traversodontids. Considering that the occlusal basin in Exaeretodon is formed by dentine (see Figure 1A), we also compare the dentine pattern on areas exposed to, and hidden from, the occlusal basin.

\section{MATERIALS AND METHODS}

The specimen of Exaeretodon frenguellii is an almost complete upper postcanine (PVL 5631; see Figure 1) deposited in the Paleontología de Vertebrados Lillo collection (PVL) at the Universidad Nacional de Tucumán, with a bucco-lingual crown width of $3.2 \mathrm{~cm}$, whereas the anteroposterior length is approximately $2.3 \mathrm{~cm}$. Specimens of $E$. riograndensis are represented by a nearly complete upper postcanine (MCP 4278-PV) and a tiny fragment of an upper postcanine (MCP 3843-PV, paratype of $E$. riograndensis) both from the Museu de Ciências e Tecnologia collection (MCP), Pontifícia Universidade Católica do Rio Grande do Sul (PUCRS).

For scanning electronic microscope (SEM) observation, the teeth were embedded in epoxy resin and cut with a diamond saw. Following terminology of plane sections for tribosphenic molars presented by Wood \& Stern (1997:fig. 1), PVL 5631 was sectioned in horizontal and sagittal plane (Figure 1), and MCP 4278-PV was sectioned horizontally. We were unable to determine the plane of section in MCP $3843-\mathrm{PV}$. The surfaces were polished and etched with $1 \mathrm{~N}$ $\mathrm{HCl}$ for 60 seconds, then washed in water. Specimens were mounted on stubs, sputter-coated with gold and observed with a SEM (Philips XL 30).

Synapsid columnar enamel (SCE) was defined on the basis of morphological features (Sander, 1997; Koenigswald \& Sander, 1997) that also seem to be present in the columnar enamel of some reptiles. Therefore, we follow Sander (1999) and refer to the prismless enamel of the synapsids (i.e., nonmammaliaform cynodonts) described and discussed in this contribution as columnar enamel, composed of columnar divergence units.
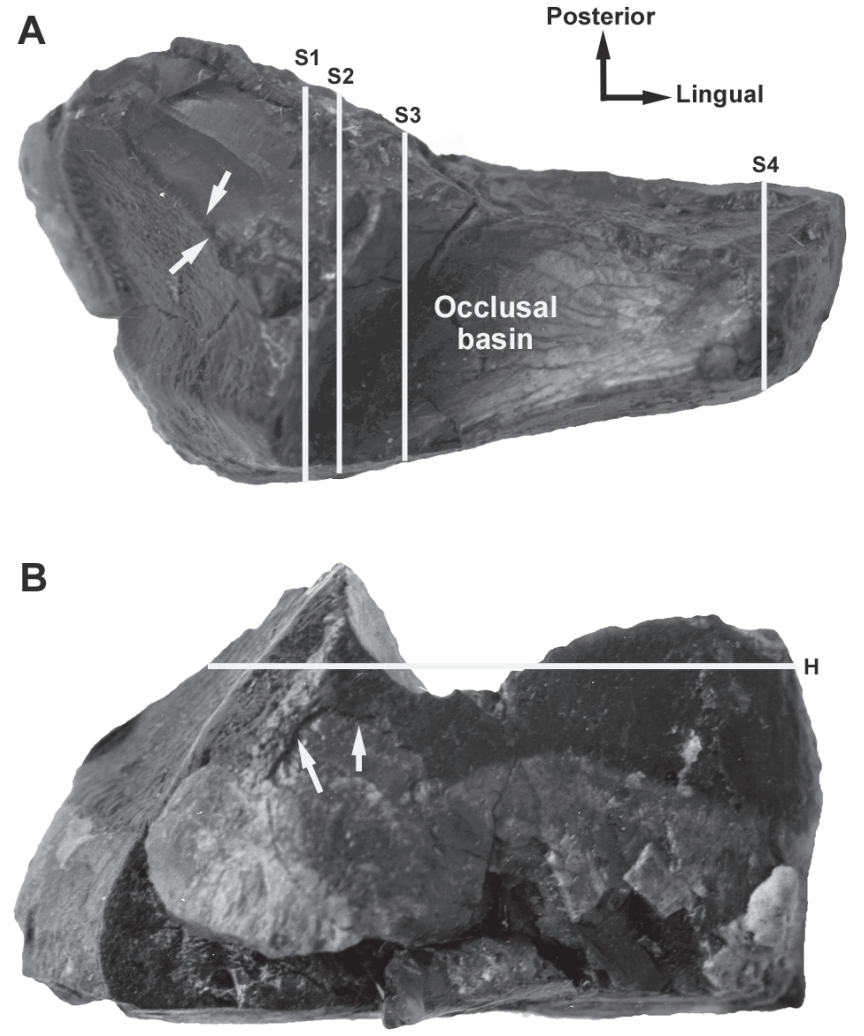

Figure 1. Occlusal (A) and anterior (B) views of the upper postcanine of Exaeretodon frenguellii (PVL 5631). The tooth is incomplete in its postero-lingual border. Sections planes are indicated. Abbreviations: $\mathbf{H}$, horizontal section; $\mathbf{S}$, sagittal sections. Arrows points to enamel layer. Plane section terminology follows Wood \& Stern (1997).

\section{RESULTS}

\section{Exaeretodon frenguellii}

Enamel layer thickness in E. frenguellii appears somewhat variable. In the horizontal section, it measures $350 \mu \mathrm{m}$, whereas it varies from $250-270 \mu \mathrm{m}$ and $70-100 \mu \mathrm{m}$ in different sagittal sections. The enamel microstructure appears as parallel columns that are oriented perpendicular to the outer enamel surface. These columns are short and discontinuous, vary in absolute size (Figure 2A-D), and have irregular cross sections (Figures 2E-F). The diameter of the columnar units close to the enamel-dentine junction (EDJ) varies between 3 and $10 \mu \mathrm{m}$. The enamel crystallites are oriented perpendicular or slightly tilted $\left(60-70^{\circ}\right)$ in relation to the EDJ (Figure 2B, D). Tubules are visible in both sagittal and horizontal sections, and in the latter are oriented slightly obliquely in relation to the EDJ (Figure 2C). Faint incremental lines are present in the enamel (Figure 2A, arrowheads).

The dentine of both the root and the crown is rich in odontoblast tubules. The tubules of dentine appear mostly perpendicular to the EDJ, but in sagittal section are aligned obliquely at $60-70^{\circ}$ to the EDJ. Areas of dentine hidden and 

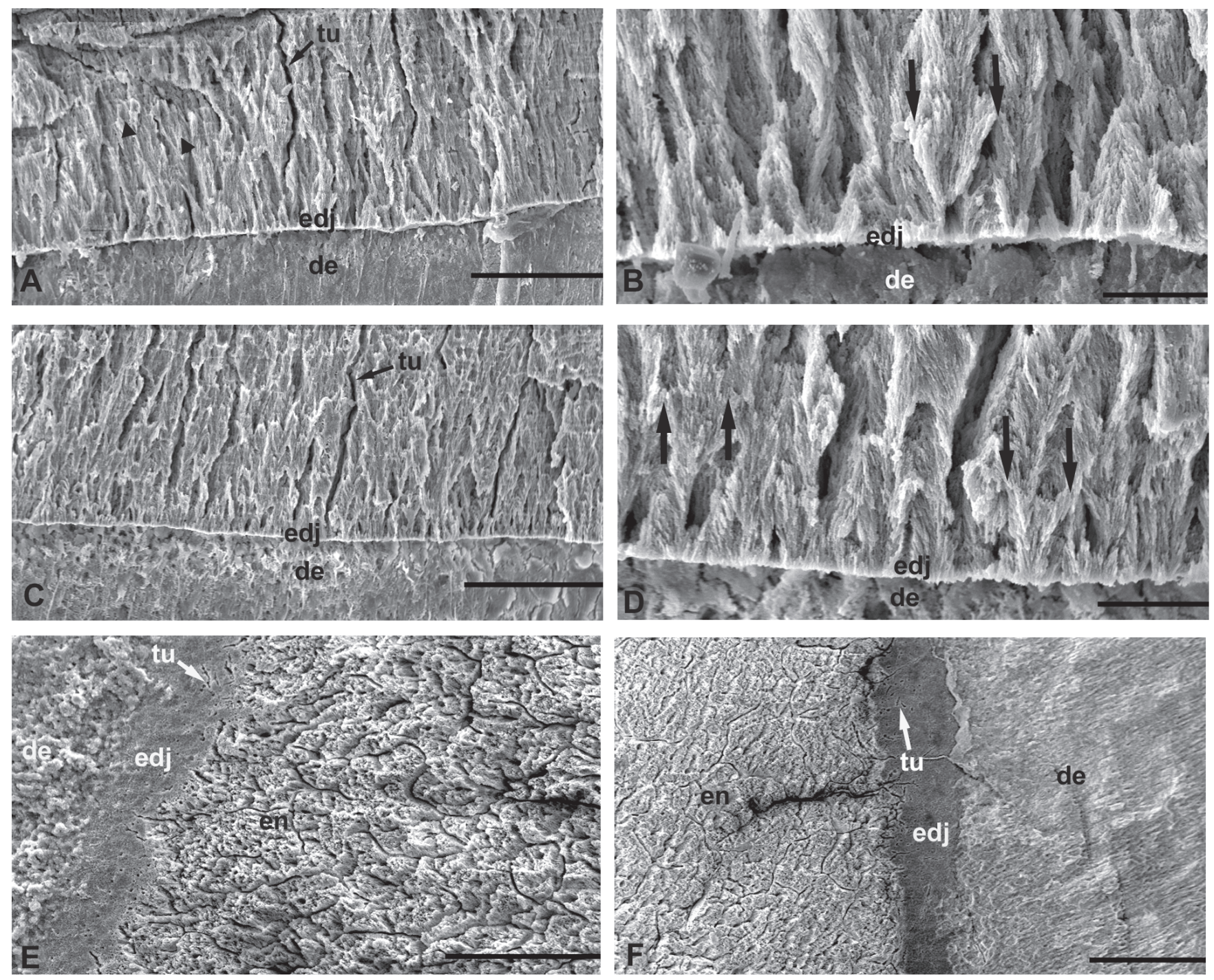

Figure 2. Enamel microstructure of Exaeretodon frenguellii (PVL 5631). A, sagittal section 4, general view of the enamel layer showing enamel tubules and faint incremental lines (arrowheads); B, sagittal section 4, close-up of A near to the enamel-dentine junction, showing orientation of enamel crystallites and columnar divergence units (whose limits are indicated by arrows); C, horizontal section, general view of the enamel showing slightly oblique enamel tubules; $\mathbf{D}$, horizontal section, close-up of $\mathbf{C}$ near to EDJ, showing orientation of enamel crystallites and divergence columnar units (whose limits are indicated by arrows); sagittal section 4 (E) and sagittal section 1 (F) showing the enamel surface near of the enamel-dentine junction; the irregular polygonal pattern of the columns of the enamel is exposed by differential etching. Note the opening of the tubules in the EDJ. The plane of section in $E$ and $F$ is at a low angle to the plane of the edj, corresponding to a tangential section of Sander (1997). Abbreviations: de, dentine; edj, enamel-dentine junction; en, enamel; tu, enamel tubules. Scale bar in $\mathrm{A}, \mathrm{C}, \mathrm{E}$ and $\mathrm{F}=50 \mu \mathrm{m}$; in $\mathrm{B}$ and $\mathrm{D}=10 \mu \mathrm{m}$.

exposed to occlusion (Figure 3A) show some difference worth mentioning. Dentine not exposed to occlusion shows a remarkable density of regular parallel tubules directed dorsoventrally (Figure 3C). However, tubules in dentine exposed to occlusion are not oriented dorsoventrally, they form an irregular network, are less conspicuous and their density appears to be reduced (Figure 3B). In the horizontal section, the tubules are sectioned transversely and their density seems to be higher in the areas of the dentine not exposed to occlusion.

\section{Exaeretodon riograndensis}

The thickness of the enamel layer in E. riograndensis is variable $(200-250 \mu \mathrm{m})$. The enamel microstructure shows notable differences in the two teeth sampled. In MCP 4278PV (Figures 4 A-D) columnar units are barely discernible, with the crystallites being slightly divergent or parallel, and do not show a central line. Incremental lines are abundant and regularly spaced, whereas enamel tubules do not appear to be abundant, and some of them are observed crossing obliquely from the dentine to the enamel (Figure 4B). In MCP 3843-PV (Figures 4E-F) the columnar units are also barely visible, but in this case, enamel tubules are remarkably abundant and some of them cross all or most of the enamel layer. Incremental lines are also abundant and regularlyspaced. 


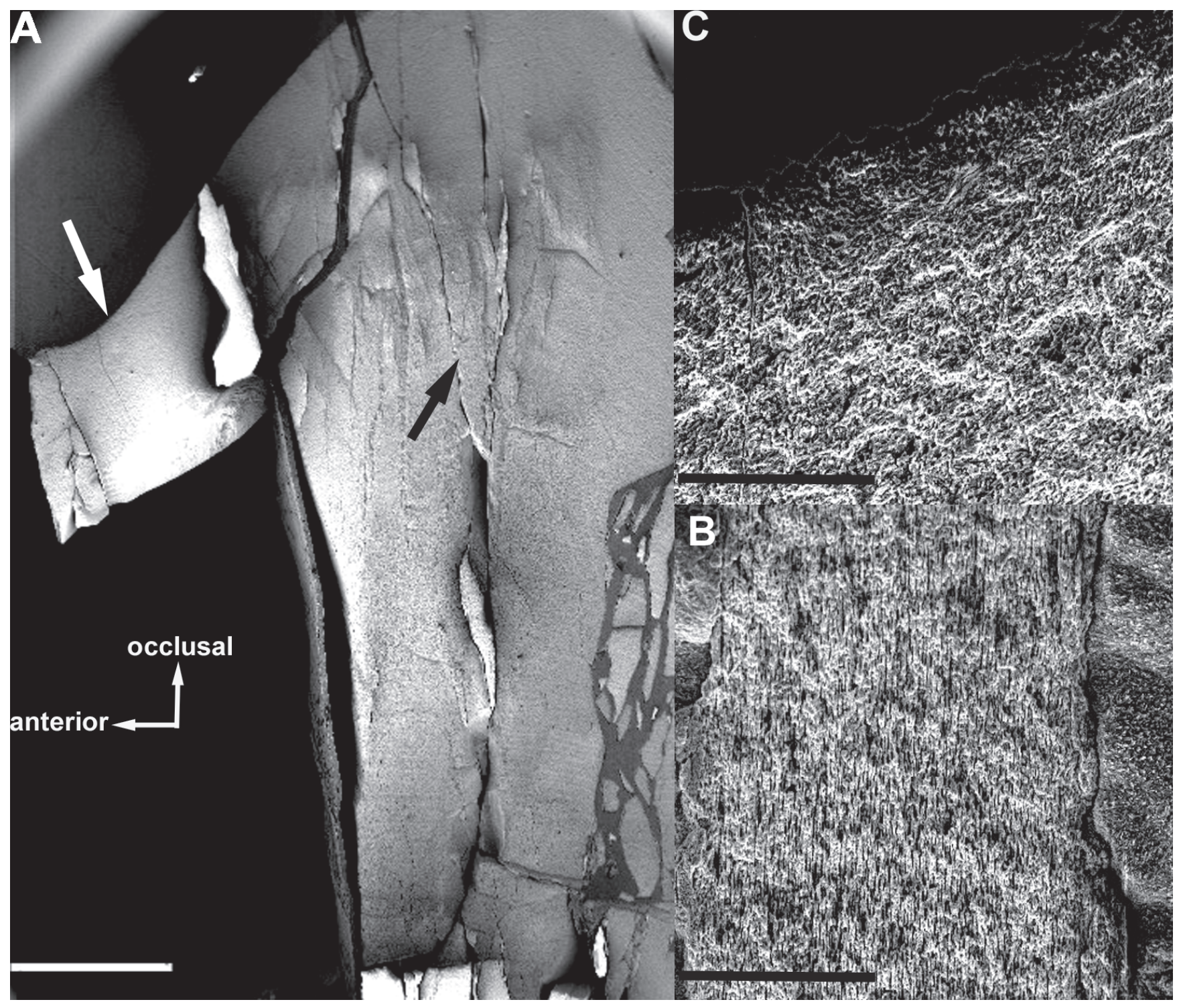

Figure 3. Dentine microstructure of Exaeretodon frenguellii (PVL 5631) in sagittal section 3. A, general view of the section of the tooth; $\mathbf{B}$, area of dentine forming part of the occlusal basin (white arrow in A); C, area of dentine not exposed to occlusion (black arrow in A). Scale bar in $A=2 \mathrm{~mm}$; in $B, C=100 \mu \mathrm{m}$.

\section{DISCUSSION AND CONCLUSION}

We examined the enamel pattern of two closely related nonmammaliaform cynodonts of the clade Traversodontidae (sensu Abdala et al., 2006). The enamel microstructure found in the two species of the traversodontid Exaeretodon confirms the consistent presence of prismless enamel in synapsids. The enamel layer in both species of Exaeretodon is thick (less than $360 \mu \mathrm{m}$ and mostly above $100 \mu \mathrm{m}$; see Sander, 1997:appendix). Considering the enormous sizes of the teeth (see in the material section), comparing the absolute thickness of the enamel with that of other nonmammaliaform cynodonts seems pointless. Columnar divergence units are clearly observed in the enamel of $E$. frenguellii, whereas the pattern in E. riograndensis is not clear. Even though the enamel microstructure in the latter species is indeed prismless, the presence of columnar divergence units is not confirmed.
Incremental lines are more clear and abundant in the enamel of $E$. riograndensis. In addition, both species show the presence of tubules that cross most of the enamel layer and apparently also the EDJ.

Columnar units in the enamel of the Exaeretodon frenguellii tooth show similarities with those observed in cross section of the basal synapsid Dimetrodon (Sander 1997:fig. 2A). Some of the sagittal sections in which the columns are visible transversally (Figure 2E, F), show some similarity with the columns observed in oblique inverse tangential section of the enamel of the traversodontid Boreogomphodon and the tritylodontid Oligokyphus (Sander, 1997:fig. 2G, H).

The enamel microstructure in MCP 3843-PV (Figure 4E, F) approaches that observed in E. frenguellii due to the presence of long tubules traversing most of the enamel, however, the presence of columnar units is not demonstrated 

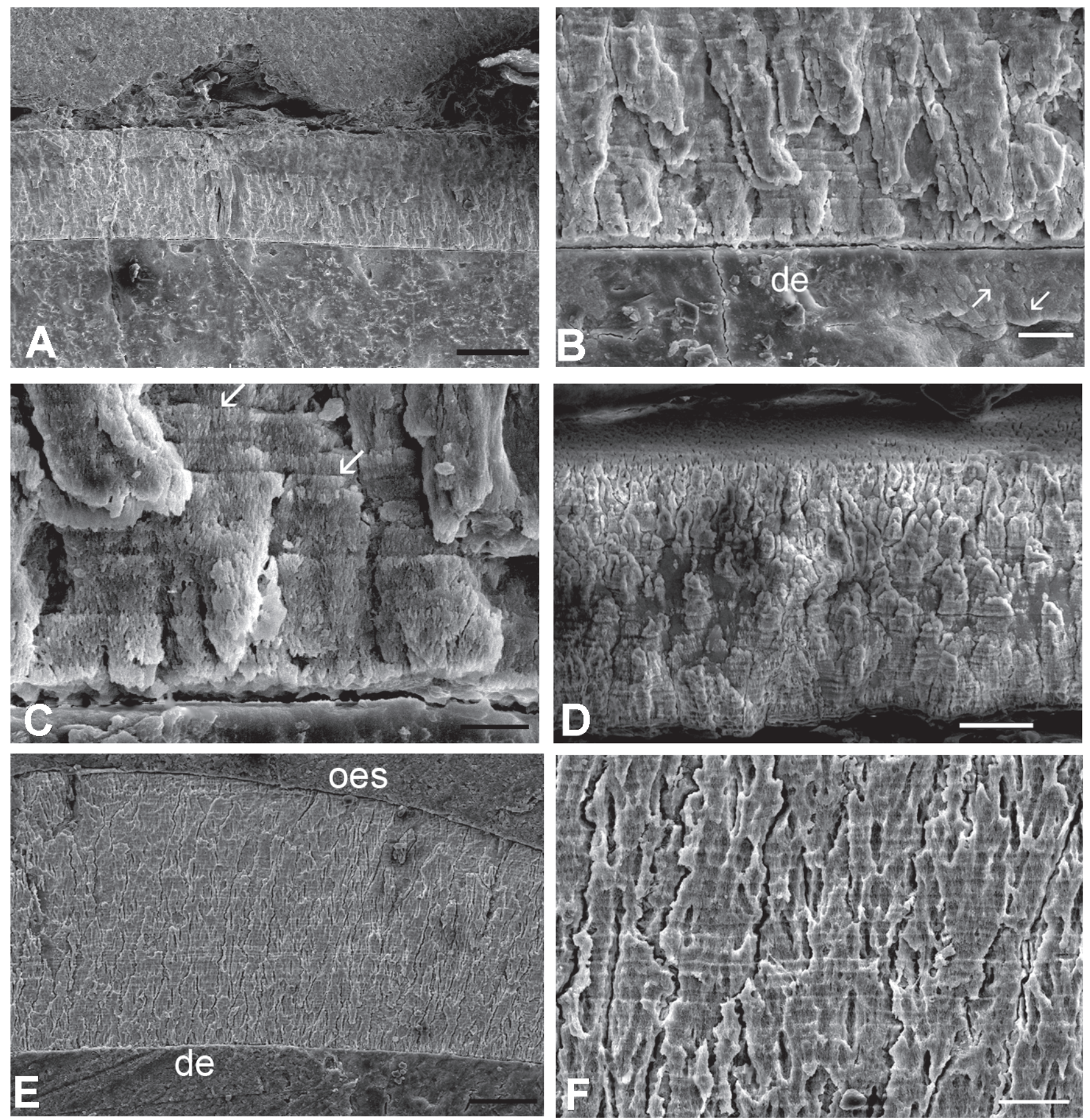

Figure 4. Enamel microstructure of Exaeretodon riograndensis. A-D, MCP 4278-PV, horizontal section; E-F, MCP 3843-PV. A, general view of the enamel layer; $\mathbf{B}$, columns close to the EDJ with a group of tubules (arrows) obliquely crossing the dentine; $\mathbf{C}$, close-up of B showing the poorly defined columns and abundance of incremental lines (arrows); D, enamel layer with the top of the columnar units; E, general view of the enamel layer; $\mathbf{F}$, close-up of $\mathrm{E}$ showing tubules and incremental lines. Abbreviations: de, dentine; oes, outer enamel surface. Scale bar in $A=200 \mu \mathrm{m} ; \mathrm{B}, \mathrm{F}=25 \mu \mathrm{m} ; \mathrm{C}=10 \mu \mathrm{m} ; \mathrm{D}=50 \mu \mathrm{m}$; in $\mathrm{E}=100 \mu \mathrm{m}$.

in this tooth. The microstructure of MCP 4278-PV (Figure 4C, D) is reminiscent of the flared and pinched columns of Massetognathus (Stern \& Crompton, 1995:fig. 12).

Our study of dentine microstructure in areas exposed to, and hidden from, occlusion show differences in the visibility and apparent abundance of tubules. Thus, dentine not exposed to occlusion shows tubules as long, clearly visible, dorsoventrally-oriented and tightly packed structures (Figure $3 \mathrm{C}$ ), whereas in areas close to the occlusal basin tubules are less conspicuous and apparently less abundant (Figure 3B). However, this difference might simply reflect the change in orientation of the tubules, that makes them less visible in areas exposed to occlusion. Future contributions should explore this difference in more detail. 


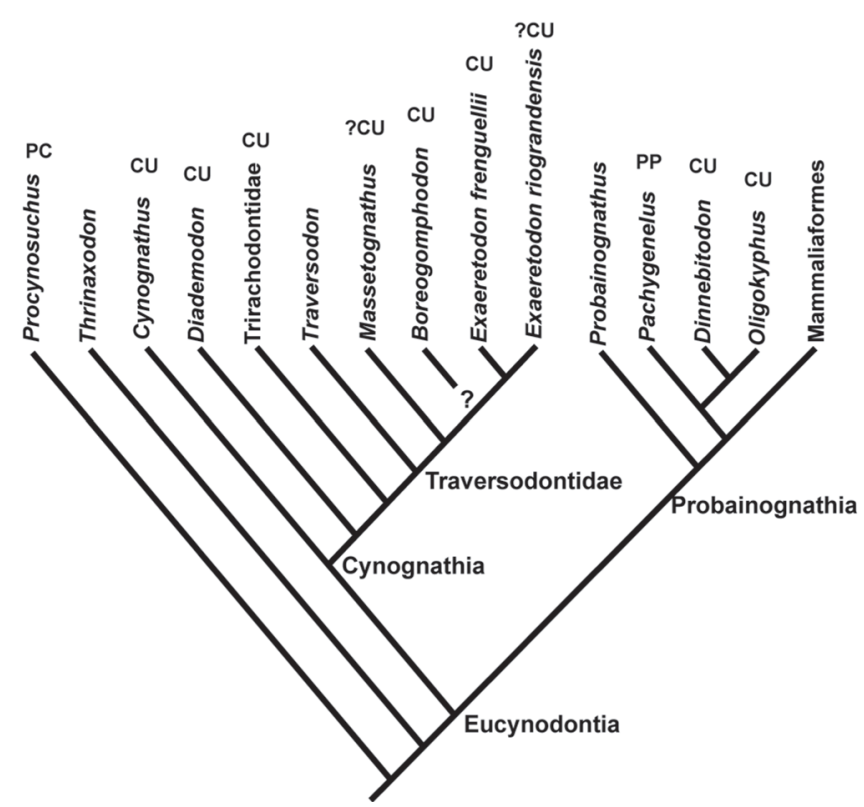

Figure 5. Relationship of nonmammaliaform cynodonts, showing the distribution of different enamel microstructures. PC, parallel crystallite; CU, columnar divergence units; PP, plesiomorphic prismatic. The cladogram, modified from Abdala (2007), is mostly restricted to taxa in which the enamel microstructure is known. Data for trirachodontids from Sahni \& Lester (1988), remaining taxa from Sander (1997) and this study.

\section{Traversodontid enamel microstructure}

The enamel microstructure of four nonmammaliaform synapsids, including an undescribed traversodontid cynodont from Tanzania, was studied using optical and polarized microscopy (Moss, 1969). Although non-prismatic, the enamel type in the synapsid examined was not totally structureless, showing bands varying from 6 to $8 \mu \mathrm{m}$ (Moss, 1969) that probably correspond to columnar divergence units. The enamel microstructure of isolated traversodontid teeth from the Pranhita Godavary Basin from India were also described (Sahni \& Lester, 1988:fig. 10). Traversodontids are not known in the mentioned basin however, and the teeth studied by Sahni \& Lester (1988) are more likely of trirachodontids, the only cynodonts represented in this basin (Chatterjee, 1982; Bandyopadhyay \& Sengupta, 1999). Sahni $\&$ Lester (1988) interpreted the enamel microstructure of these teeth as suggestive of prismatic structure, but with the putative prisms being inconspicuous and discontinuous through the enamel layer. The microstructure of the enamel observed in the only illustration of these teeth (Sahni \& Lester, 1988: fig. 10) could be interpreted as columnar instead. Sahni \& Lester (1988) also describe well-defined incremental lines and tubules that crossed the EDJ. The enamel microstructure of a Middle Triassic Massetognathus tooth was studied by transmitted and polarized light microscopy (Osborn \& Hillman, 1979). These authors reported the presence of light and dark bands, together measuring approximately $5 \mu \mathrm{m}$ in width (see Osborn \& Hillman, 1979:fig. 4). The bands were interpreted as changes in the orientation of the enamel crystallites, and the microstructure was considered as prismatic, lacking interprismatic regions. These authors also described and illustrated many enamel tubules observed in tangential section (Osborn \& Hillman, 1979:fig. 11). The enamel of Massetognathus was also studied using SEM, and described as columnar (Stern \& Crompton, 1995). The columns were flared and repeatedly pinched, and faint incremental lines were coincidental with flaring areas of the column. Recently, however, Sander (1997:appendix) considered the presence of a columnar enamel microstructure in this taxon as uncertain. On the etched outer surface of the tooth, "perikymata-like" structures were interpreted as the result of partially etched rows of columns surrounded by intercolumnar enamel (Stern \& Crompton, 1995). Tubules in the enamel of Massetognathus are not mentioned by these authors (contra Osborn \& Hillman, 1979). Columnar enamel is also present in the Laurasian traversodontid Boreogomphodon, however the only published image (Sander 1997:fig. 2G) does not show whether the enamel had tubules and incremental lines.

In summary, traversodontid enamel is prismless, with columnar divergence units that may be clearly or poorly defined. Tubules and incremental lines are observed in most traversodontid teeth, and the latter can be conspicuous (e.g., Exaeretodon riograndensis) or faint (e.g., E. frenguellii, Massetognathus).

\section{CONCLUDING REMARKS}

Even though research on synapsid dental microstructure has increased particularly in the last decade, our knowledge of enamel microstructures in nonmammaliaform cynodonts remains limited. Besides that of the traversodontid cynodonts discussed above, a cursory description of the enamel of Thrinaxodon and Diademodon highlighted the lack of prisms and patternless structure (Grine et al., 1979a). In addition, these authors reported the presence of bands or circumferential lamellae (= incremental lines) parallel to the outer enamel surface in the enamel of Diademodon (Grine et al., 1979a:fig. 3). The tritheledontid Pachygenelus is indeed the most studied nonmammaliaform cynodont to date, with the enamel being investigated in South African (Grine et al., 1979b; Grine \& Vrba, 1980) and North American (Stern \& Crompton, 1995; Wood \& Stern, 1997) specimens. Tritylodontids were also extensively sampled: the enamel pattern of Oligokyphus (Dauphin \& Jaeger, 1987; Sander, 1997) unidentified tritylodontids from the United States (Stern \& Crompton, 1995; Wood \& Stern, 1997) and from Japan (Kamiya et al., 2006) were reported and illustrated; the enamel microstructure of the tritylodontid Dinnebitodon was investigated but not illustrated (see Sander, 1997:appendix); and Tritylodon enamel was described as continuous and patternless (Grine et al., 1979b). In the most recent survey of enamel microstructure in nonmammaliaform synapsids, Sander (1997) investigated nine cynodont taxa: Procynosuchus, Cynognathus, Diademodon, Boreogomphodon, Oligokyphus, Dinnebitodon, Microconodon, Tricuspes, and Pachygenelus (although only Boreogomphodon, Oligokyphus and Pachygenelus were illustrated). Our current 
knowledge of enamel pattern is restricted to twelve nonmammaliaform cynodonts that, considering the current diversity of the group, represents approximately $13 \%$ (Abdala, pers. obs.). Even with this scarcity of sampling, three different enamel microstructures were found among representatives of this group, with columnar enamel most common (Figure 5). Departures from this are represented by the basal cynodont Procynosuchus with parallel crystallite enamel (Sander, 1997) and the extensively sampled and illustrated Pachygenelus showing enamel with plesiomorphic prisms (Sander, 1997; Wood \& Stern, 1997; Wood \& Rougier, 2005). In addition, a recent report describes prisms in a Lower Cretaceous tritylodontid from Japan (Kamiya et al., 2006).

Traversodontid cynodonts are remarkably diverse and abundant in South American faunas. Description of the enamel of the Late Triassic traversodontid Exaeretodon represents our first effort in surveying teeth of South American nonmammaliaform cynodonts. Future contributions will provide data on the enamel of Early and Middle Triassic traversodontids. These studies will allow a broad characterization of the enamel microstructure(s) of this diverse and long-lived family of nonmammaliaform cynodonts.

\section{ACKNOWLEDGMENTS}

The authors are indebted to J. Powell (PVL), for providing access to the material studied; to M. M. de Oliveira and F. Weiss for supporting this project from the very beginning; to M. Richter for technical advice, encouragement and comments on a first draft; to A. de Mattos and G. Machado (CEMM, PUCRS) for assistance with the use of the scanning electron microscope. Helpful reviews by J. Botha-Brink, D. Kalthoff and M. Sander are especially recognized. Financial support was provided by PUCRS, PAST (Palaeontological Scientific Trust, Johannesburg) and the Oppenheimer Foundation.

\section{REFERENCES}

Abdala, F. 2007. Redescription of Platycraniellus elegans (Therapsida, Cynodontia) from the Lower Triassic of the Karoo Basin, South Africa, and the cladistic relationships of eutheriodontids. Palaeontology, 50:591-618.

Abdala, F.; Barberena M.C. \& Dornelles, J. 2002. A new species of the traversodontid cynodont Exaeretodon from the Santa Maria Formation (Middle/Late Triassic) of southern Brazil. Journal of Vertebrate Paleontology, 22:313-325.

Abdala, F.; Neveling, J. \& Welman, J. 2006. A new trirachodontid cynodont from the lower levels of the Burgersdorp Formation (Lower Triassic) of the Beaufort Group, South Africa and the cladistic relationships of Gondwanan gomphodonts. Zoological Journal of the Linnean Society, 147:383-413.

Abdala, F. \& Ribeiro, A.M. 2003. A new traversodontid cynodont from the Santa Maria Formation (Ladinian-Carnian) of southern Brazil, with a phylogenetic analysis of Gondwanan traversodontids. Zoological Journal of the Linnean Society, 139:529-545.
Bandyopadhyay, S. \& Sengupta, D.P. 1999. Middle Triassic vertebrates of India. Journal of African Earth Sciences, 29:233-241.

Bonaparte, J.F. 1982. Faunal replacement in the Triassic of South America. Journal of Vertebrate Paleontology, 2:362-371.

Cabrera, A. 1943. El primer hallazgo de terápsidos en la Argentina. Notas del Museo de La Plata 8:317-331.

Chatterjee, S. 1982. A new cynodont reptile from the Triassic of India. Journal of Paleontology, 56:203-214.

Clemens, W.A. 1997. Characterization of enamel microstructure and application of the origins of prismatic structures in systematic analyses. In: W.v. Koenigswald \& P.M. Sander (eds.) Tooth enamel microstructure, A.A. Balkema, p. 85-112.

Crompton, A.W. 1972. Postcanine occlusion in cynodonts and tritylodontids. Bulletin of the British Museum (Natural History), Geology, 21:29-71.

Crompton, A.W.; Wood, C.B. \& Stern, D.N. 1994. Differential wear of enamel: a mechanism for maintaining sharp cutting edges. Advances in Comparative and Environmental Physiology, 18:321-346.

Dauphin, Y. \& Jaeger, J.-J. 1987. Présence de prismes dans l'émail des dents jugales d'Oligokyphus (Synapsida, Tritylodontidae): implications phylétiques. Comptes rendus de l'Académie des Sciences de Paris, Serie 2, 304:941-944.

Grine, F.E.; Gow, C.E. \& Kitching, J.W. 1979b. Enamel structure in the cynodonts Pachygenelus and Tritylodon. Proceedings Electron Microscopy Society of Southern Africa, 9:99-100.

Grine, F.E. \& Vrba, E.S. 1980. Prismatic enamel: a pre-adaptation for mammalian diphyodonty? South African Journal of Science, 76:139-141.

Grine, F.E.; Vrba, E.S. \& Cruickshank, A.R.I. 1979a. Enamel prisms and diphyodonty: linked apomorphies of Mammalia. South African Journal of Science, 75:114-120.

Hopson, J.A. 1984. Late Triassic traversodontid cynodonts from Nova Scotia and Southern Africa. Palaeontologia Africana, 25:181-201.

Hopson, J.A. \& Barghusen, H.R. 1986. An analysis of therapsid relationships. In: N. Hotton III; P.D. MacLean; J.J. Roth \& E.C. Roth (eds.) The ecology and biology of the mammal-like reptiles, Smithsonian Institution Press, p. 83-106.

Kamiya, H.; Yoshida, T.; Kusuhashi, N. \& Matsuoka, H. 2006. Enamel texture of the tritylodontid mammal-like reptile, occurred from the Lower Cretaceous in central Japan. Material Science and Engineering C, 26:707-709.

Koenigswald, W.v. \& Sander, P.M. 1997. Glossary of terms used for enamel microstructures. In: W.v. Koenigswald \& P.M. Sander (eds.) Tooth enamel microstructure. A.A.Balkema, p. 267-280.

Luo, Z. 1994. Sister-group relationships of mammals and transformations of diagnostic mammalian characters. In: N.C. Fraser \& H.-D. Sues (eds.) In the Shadow of the Dinosaurs: Early Mesozoic Tetrapods, Cambridge University Press, p. 98 128.

Moss, M.L. 1969. Evolution of mammalian dental enamel. American Museum Novitates, 2360:1-39. Osborn, J.F. \& Hillman, J. 1979. Enamel structure in some therapsids and Mesozoic mammals. Calcified Tissue International, 29:47-61.

Sahni, A. \& Lester, K.S. 1988. The nature and significance of enamel tubules in therapsids and mammals. In: D.E. Russell; J.-P. Santoro \& D. Sigogneau-Russell (eds.) Teeth revisited: Proceedings of the VIIIth International Symposium on Dental Morphology, p. 85-99. 
Sander, P.M. 1997. Non-mammalian synapsid enamel and the origin of mammalian enamel prisms: the bottom-up perspective. In: W.v. Koenigswald \& P.M. Sander (eds.) Tooth enamel microstructure. A.A.Balkema, p. 41-62.

Sander, P.M. 1999. The microstructure of reptilian tooth enamel: terminology, function, and phylogeny. Münchner Geowissenschaftliche Abhandlungen, 38:1-102.

Sander, P.M. 2000. Prismless enamel in amniotes: terminology, function, and evolution. In: M. Teaford, M.W.J. Ferguson \& M.M. Smith (eds.) Development, Function and Evolution of Teeth, Cambridge University Press, p. 92-106.
Stern, D.N. \& Crompton, A.W. 1995. A study of enamel organization, from reptiles to mammals. In: J. Moggi-Cecchi (ed.) Aspects of dental biology: Palaeontology, Anthropology and Evolution. International Institute for the Study of Man, p. $1-25$.

Wood, C.B. \& Rougier, G.W. 2005. Updating and recoding enamel microstructure in mesozoic mammals: in search of discrete characters for phylogenetic reconstruction. Journal of Mammalian Evolution, 12:433-460.

Wood, C.B. \& Stern, D.N. 1997. The earliest prism in mammalian and reptilian enamel. In: W.v. Koenigswald \& P.M. Sander (eds.) Tooth enamel microstructure, A.A.Balkema, p. 63-83.

Received in February, 2007; accepted in June, 2007 